\title{
FORMULATION DEVELOPMENT AND EVALUATION OF ORALLY DISINTEGRATING TABLET OF CHLORPHENERAMINE MALEATE BY SUBLIMATION TECHNIQUE
}

\author{
NILESH R. BHOSALE*, NIKITA S. KOLTE \\ Department of Pharmaceutics, Pune District Education Association's, Seth Govind Raghunath Sable College of Pharmacy, Saswad 412301, \\ Tal-Purandar, Dist Pune, Maharashtra, India \\ Email: nilesh.bhosale01@gmail.com
}

Received: 30 May 2019 Revised and Accepted: 25 Jul 2019

\section{ABSTRACT}

Objective: Chlorpheneramine maleate is a first-generation antihistamine drug used in the treatment of allergic conditions like rhinitis, urticaria, and cough cold, etc. In present work, the challenge has been made to develop an orally disintegrating tablet of chlorpheneramine maleate with an increase in bioavailability and patient compliance.

Methods: The sublimation technique was used to prepare orally disintegrating tablets. Porous tablet prepared after sublimation of camphor at 60 ${ }^{\circ} \mathrm{C}$ in a hot air oven for $60 \mathrm{~min}$. In the research work, $3^{2}$ full factorial design used to find out the effect of two variables like the amount of Crospovidone and Croscarmellose sodium.

Results: All prepared formulations were analyzed for various parameters. DSC of pure drug and optimized formulation A (9) showed purity of sample and compatibility of all ingredients with each other. In FTIR study of pure drug and optimized formulation A (9) no major shifts were seen. An optimized formulation (A9) was found to have good hardness (3.2 kg/cm2), friability ( $<1 \%)$, disintegration time (26 s), \% drug release (99.77 \%) within 6 min.

Conclusion: The result obtained showed that orally disintegrating tablet of chlorpheneramine maleate enhances dissolution rate, improves bioavailability which will improve patient compliance.

Keywords: Chlorpheneramine maleate, Orally disintegrating tablet, Crospovidone, Croscarmellose sodium, Sublimation, Factorial design

(c) 2019 The Authors. Published by Innovare Academic Sciences Pvt Ltd. This is an open access article under the CC BY license (http://creativecommons.org/licenses/by/4.0/) DOI: http://dx.doi.org/10.22159/ijpps.2019v11i9.34387

\section{INTRODUCTION}

The drug can be delivered to the systemic circulation by various routes of administration but among them, the oral route of drug delivery is more common. Oral drug delivery provides advantages of selfmedication, ease of administration, harmless [1,2]. Now a day's efforts have been taken to ease of administration of the drug. In patients' point of view, the orally disintegrating tablet is an attractive dosage form to all age patients [3]. The orally disintegrating tablet is a solid dosage form that gets easily disintegrate or dissolve when put on the tongue without the need for water. Many patients face problems in swallowing tablet dosage form, to overcome this problem tablets are made that easily disintegrate in saliva before swallowing. Orally disintegrating tablets provide benefits to pediatric and geriatric patients, patients who have a swallowing problem, traveling patients who are not able to maintain water all the time. Orally disintegrating tablets avoid the first-pass metabolism of the drug as absorption takes place through mouth, pharynx, and esophagus as saliva passes down into the stomach. In such cases, the bioavailability of the drug gets increases and improves patient compliance [4-6]. As the drug is easily disintegrating, the drug comes in contact with taste bud so taste masking of the drug can be done to improve good mouthfeel. The bitter drug should be administered after proper taste-masking to give good palatability [7-9]. Rapid onset of action, improvement in dissolution rate, accurate dosing, avoid suffocation due to physical obstruction, good mouthfeel, no need of water are the advantages of orally disintegrating tablets that increase acceptance criteria of the patient to use these dosage form.

Chlorpheneramine maleate is a first-generation alkylamine antihistamines agent. The normal dose is about $4 \mathrm{mg}$ every 4-6 $\mathrm{h}$. Bioavailability is about 25-60\% with $70 \%$ protein binding. Half-life is about 12-15 h. Desmethylchlorpheneramine and didesmethylchlorpheneramine are the by-products of the metabolism of drug which lowers its bioavailability. It is used in the treatment of allergic conditions like rhinitis, urticaria, watery eyes, cough, and cold. It acts by binding to the $\mathrm{H}_{1}$ receptor and block the action of endogenous histamine, which respite symptoms of histamine. Common adverse effects are CNS depression, diarrhea, vomiting, dry mouth [10-12]

The aim of this work was to develop an orally disintegrating tablet by sublimation technique. The key to providing rapid disintegration of tablets by creating a porous structure in the tablet matrix. Camphor is used as a sublimating agent to develop pores after sublimation [13]. Crospovidone and Croscarmellose sodium are used as super disintegrant due to its capillary action [14-16] Mannitol is used as the diluent and also useful in taste masking as it provides a good mouthfeel. Sodium saccharin and orange flavor are used as taste-masking agents [17]

\section{MATERIALS AND METHODS}

\section{Materials}

Chlorpheneramine maleate was obtained from (Yarrow chemicals Mumbai) and Crospovidone, Croscarmellose sodium (Vergo, Goa), Camphor, Sodium saccharin, Mannitol, Talc, Magnesium stearate, Orange flavor (Research lab, Fine chem. Industries, Mumbai.)

\section{Method}

\section{Characterization of drug and excipients}

\section{Differential scanning calorimetry (DSC)}

The DSC pattern was analyzed by METTLER TOLEDO (Star SW 920). Pure drug and physical mixture of drug and excipients were heated in a crimped aluminum pan with a pierced lid at a scanning rate of $10{ }^{\circ} \mathrm{C} / \mathrm{min}$ in an atmosphere of nitrogen flow $(40 \mathrm{ml} / \mathrm{min})$ in the range of $30-350{ }^{\circ} \mathrm{C}$

\section{Fourier transform infrared spectroscopy (FTIR)}

The FT-IR spectrum of pure drug and physical mixture of drug and excipients were recorded on FTIR spectrophotometer (FTIR 8400S, Shimadzu) using KBr powder press technique. The instrument was operated under dry air purge with the resolution of $\mathrm{cm}^{-1}$ over the region $4000-400 \mathrm{~cm}^{-1}$. 


\section{Formulation of orally disintegrating tablets}

Preliminary batches for selection of a concentration of sublimating agent

Camphor was selected as a sublimating agent for this work. Batches with various concentrations of camphor were taken to determine the optimized concentration of camphor. The composition for preliminary batches was mention in table 1 .

\section{Composition for factorial batches}

The orally disintegrating tablet was prepared by the sublimation technique. Drug and all other excipients without lubricant were passed through mesh no 60. Care should be taken for proper mixing of drug and excipient. The obtained mixture of drug and excipients were lubricated with talc and magnesium stearate. The resultant mixtures were directly compressible into a tablet using $8 \mathrm{~mm}$ round flat punches using 16 stationary tableting machine. After compression tablets were subjected to sublimation, by put in a hot air oven at $60{ }^{\circ} \mathrm{C}$ for $60 \mathrm{~min}$. to generate porous structure in tablets. The composition of each tablet was mention in table 2 [18-19].

\section{$3^{2}$ Full factorial designs}

A $3^{2}$ full factorial design was examined to study the combined effect of two formulation variables-the amount of Crospovidone (X1) and Croscarmellose sodium (X2) at three-level (low, medium, high) and composition mention in (table 3). Disintegration time (DT) and \% friability were taken as dependent variables.

Table 1: Composition of sublimating agent

\begin{tabular}{|c|c|c|c|}
\hline Ingredients (mg) & N1 & N2 & N3 \\
\hline Chlorpheneramine maleate & 4 & 4 & 4 \\
\hline Crospovidone & 5 & 5 & 5 \\
\hline Croscarmellose sodium & 5 & 5 & 5 \\
\hline Camphor & 10 & 15 & 20 \\
\hline Saccharin sodium & 2 & 2 & 2 \\
\hline Orange flavor & 2 & 2 & 2 \\
\hline Magnesium stearate & 3 & 3 & 3 \\
\hline Talc & 3 & 3 & 3 \\
\hline Mannitol & 116 & 111 & 106 \\
\hline Total & 150 & 150 & 150 \\
\hline Disintegration time & $42 \mathrm{sec}$ & $39 \mathrm{sec}$ & $34 \mathrm{sec}$ \\
\hline
\end{tabular}

(Total weight of each tablet is $150 \mathrm{mg}$ )

Table 2: Composition of various batches of chlorpheneramine maleate tablet as per $3^{2}$ full factorial designs

\begin{tabular}{|c|c|c|c|c|c|c|c|c|c|}
\hline Ingredients (mg) & A1 & A2 & A3 & A4 & A5 & A6 & A7 & A8 & A9 \\
\hline Chlorpheneramine maleate & 4 & 4 & 4 & 4 & 4 & 4 & 4 & 4 & 4 \\
\hline Crospovidone & 5 & 5 & 5 & 10 & 10 & 10 & 15 & 15 & 15 \\
\hline Croscarmellose sodium & 5 & 10 & 15 & 5 & 10 & 15 & 5 & 10 & 15 \\
\hline Camphor & 20 & 20 & 20 & 20 & 20 & 20 & 20 & 20 & 20 \\
\hline Saccharin sodium & 2 & 2 & 2 & 2 & 2 & 2 & 2 & 2 & 2 \\
\hline Orange flavor & 2 & 2 & 2 & 2 & 2 & 2 & 2 & 2 & 2 \\
\hline Magnesium stearate & 3 & 3 & 3 & 3 & 3 & 3 & 3 & 3 & 3 \\
\hline Talc & 3 & 3 & 3 & 3 & 3 & 3 & 3 & 3 & 3 \\
\hline Mannitol & 106 & 101 & 96 & 101 & 96 & 91 & 96 & 91 & 86 \\
\hline Total & 150 & 150 & 150 & 150 & 150 & 150 & 150 & 150 & 150 \\
\hline
\end{tabular}

(Total weight of each tablet is $150 \mathrm{mg}$ ) mg-milligram

Table 3: Amount of variables in factorial designs

\begin{tabular}{lll}
\hline Coded value & Actual values & \\
\hline & $\mathbf{X}_{1}: \mathbf{C P}$ & $\mathbf{X}_{2}: \mathbf{C C S}$ \\
\hline-1 & 5 & 5 \\
0 & 10 & 10 \\
+1 & 15 & 15 \\
\hline
\end{tabular}

( $\mathrm{X}_{1}-$ Crospovidone, $\mathrm{X}_{2}-$ Croscarmellose sodium)

\section{Evaluation of prepared orally disintegrating tablet}

\section{Precompression parameters}

\section{Bulk density}

Bulk density was determined by pouring the blend into a graduated cylinder. it is obtained by dividing the weight of the sample in grams by final volume [20]

Bulk density can be determined by the following formula-

$$
\text { Bulk density }=\frac{\text { Weight of powder }}{\text { Volume }}
$$

\section{Tapped density}

The measuring cylinder containing a known mass of blend was tapped for 100 times [20]

Tapped density can be determined by the following formula-

$$
\text { Tapped density }=\frac{\text { Weight of powder }}{\text { tapped volume }}
$$

\section{Compressibility index}

Carr's index was measured by the following formula [20]. 


$$
\text { Carr's index }(\%)=\frac{\text { Tapped density }- \text { bulk density }}{\text { Tapped density }} \times 100
$$

\section{Hausner ratio}

Hausner ratio was determined from the ratio tapped density to bulk density using the following formula [20].

$$
\text { Hausner's ratio }=\frac{\text { Tapped density }}{\text { Bulk density }}
$$

\section{Angle of repose}

The angle of repose was determined by using the fixed funnel method. The blend was poured through a funnel that can be raised vertically until a maximum cone height $(\mathrm{h})$ was obtained. The radius of the heap (r) was measured and the angle of repose was determined by using formula [20].

$$
\text { Angle of repose }=\tan ^{-1} \frac{\mathrm{h}}{\mathrm{r}}
$$

\section{Post compression parameters}

\section{Hardness}

The hardness of tablets is an important factor in the development of ODTs as excessive crushing strength of tablets reduces disintegration time. The hardness of the tablet measured by Digital hardness tester and expressed in $\mathrm{kg} / \mathrm{cm}^{2}$ [21].

\section{Thickness}

Thickness was measured by using Vernier calipers and expressed in $\mathrm{mm}[21]$.

\section{Friability}

Friability is the measurement of tablet strength. Roche friabilator (FT1020, Labindia) was used for testing the friability using the following procedure. 10 tablets were weighed accurately and placed in the tumbling apparatus that revolves at $25 \mathrm{rpm}$ for $4 \mathrm{~min}$, dropping the tablets through a distance of six inches with each revolution. After 100 revolutions, the tablets were weighed and the $\%$ friability was calculated measured using the formula [22].

Friability $=\frac{\text { Initial weight of tablets }- \text { Final weight of tablets }}{\text { Initial weight of tablets }} \times 100$

\section{Wetting time}

A petri-dish containing $6 \mathrm{ml}$ of distilled water was taken and tissue paper folded twice was placed in it. A tablet having amaranth powder on the upper surface was placed on the filter paper. The time required to develop a red color on the surface of the tablet was recorded [23].

\section{Water absorption ratio}

A pre-weighed tablet (Wa) was placed in a petri dish the same as procedure describes in wetting time. After the tablet was absorbed water completely it was removed and weight was noted $(\mathrm{Wb})$. Water absorption ratio $\mathrm{R}$ calculated as [24].

$$
\mathrm{R}=\frac{\mathrm{W}_{\mathrm{a}-\mathrm{W}_{\mathrm{b}}}}{\mathrm{W}_{\mathrm{b}}} \times 100
$$

\section{Weight variation}

Weight variation test was performed for twenty tablets from each batch using electric balance and the average value was calculated [25].

\section{Disintegration time}

In vitro disintegration time was measured by using the disintegration test apparatus at $37^{\circ} \mathrm{C}$ using distilled water. The time taken for complete disintegration of the tablet was recorded in second [25].

\section{Drug content}

Ten tablets were weighed and made in fine powder, a quantity equivalent to $4 \mathrm{mg}$ of Chlorpheneramine maleate was weighed and dissolved in a suitable quantity of $\mathrm{pH}$ 6.8. The Chlorpheneramine maleate content was determined by measuring absorbance at 264 $\mathrm{nm}$ using UV-visible Spectrophotometer. The drug content was determined by using the standard calibration curve [23-24].

\section{In vitro drug release study}

In vitro drug release of the tablet was carried out using USP dissolution testing apparatus II (Paddle). The dissolution testing was carried out using $900 \mathrm{ml}$ phosphate buffer $\mathrm{pH} 6.8$, at $37^{\circ} \mathrm{C}$ and 50 $\mathrm{rpm}$. A sample of $5 \mathrm{ml}$ was withdrawn at 2, 4, 6, 8, $10 \mathrm{~min}$. The sample was replaced with a fresh dissolution medium of the same quantity. The sample was analyzed at $264 \mathrm{~nm}$ by using UVspectrophotometer. The percentage of drug release was calculated using the equation obtained from the calibration curve [24-26].

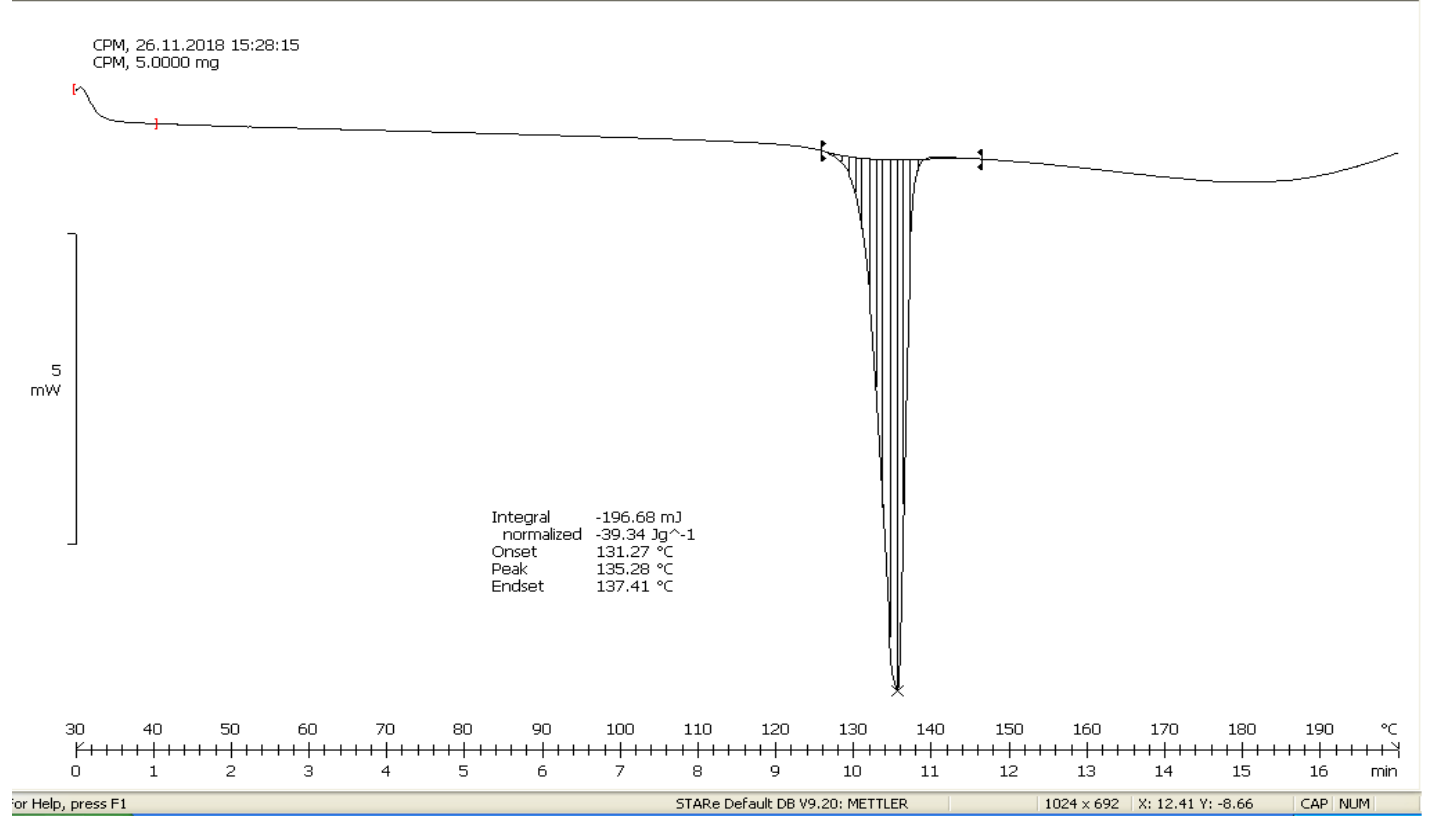

Fig. 1: DSC of pure drug 


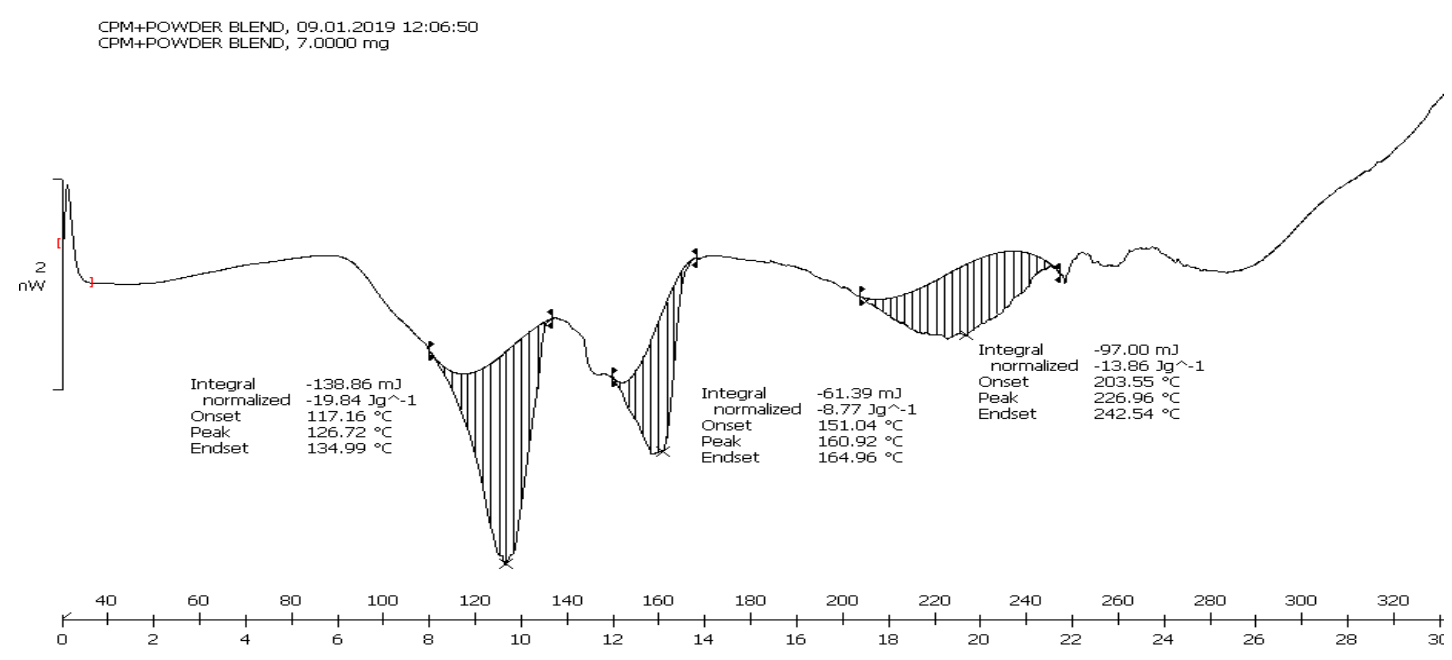

Fig. 2: DSC of optimized formulation (A9)

\section{Scanning electron microscopy (SEM)}

Optimized formulation from the factorial study was analyzed for the porous nature of the tablet by using the SEM technique [23].

\section{Stability study}

Stability studies were carried out on optimized formulation as per ICH specifications. The tablet was stored at $40 \pm 2{ }^{\circ} \mathrm{C} / 75 \pm 5 \% \mathrm{RH}$ for the duration of three mo. After an interval of one mo, the sample was withdrawn and analyzed for organoleptic properties, hardness, and disintegration time [23-25].

\section{RESULTS}

\section{Characterization of drug and excipients}

\section{Differential scanning calorimetry (DSC)}

Thermal analysis of pure drug and optimized formulation (A9) was carried out by using Stare SW920. The DSC thermogram of the pure drug showed a sharp endothermic peak at $135{ }^{\circ} \mathrm{C}$ which indicates the crystalline nature of the drug. Optimized formulation showed that there was no interaction between drug and excipients (fig. 1 and fig. 2)

\section{Fourier transform infrared spectroscopy (FTIR)}

IR spectra showed that there was no interaction between drug and excipients (fig. 3 and fig. 4).

\section{Precompression parameters}

Bulk density, tapped density, compressibility index, Hausner's ratio, angle of repose of all batches were summarized in (table 4). The result obtained for all batches was concluded that good flow properties for tablet blends.

\section{Post compression parameters}

All results were summarized in (table 5 and 6).

Hardness- Hardness of tablet was found to be in the range 3.1 to 3.2 $\mathrm{kg} / \mathrm{cm}^{2}$ indicating good strength of tablets to withstand stress during transportation.

Thickness- Thickness of tablet was found a uniform for all batches, 3.22 to $3.25 \mathrm{~mm}$.

Friability- \% friability was found to be in range 0.51 to $0.70 \%$

Wetting time-The wetting time was found to be in range $32 \pm 1.46$ to $42 \pm 1.23 \mathrm{~s}$.

Water absorption ratio-It was found between the ranges $70.27 \pm 0.41$ to $75.86 \pm 0.35 \%$.

Weight variation- The prepared formulation comply weight variation test as per IP in the range $145 \pm 1.48 \mathrm{mg}$ to $149 \pm 2.18 \mathrm{mg}$.

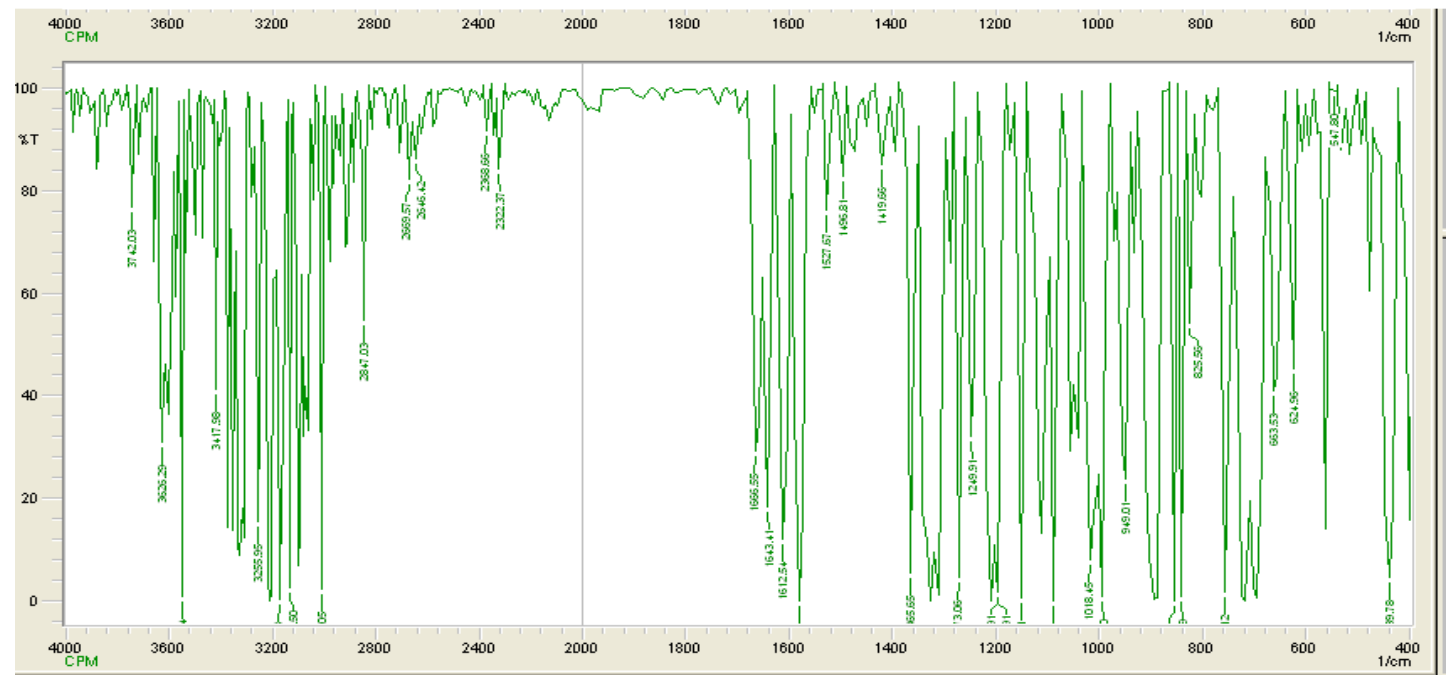

Fig. 3: FTIR of pure drug 


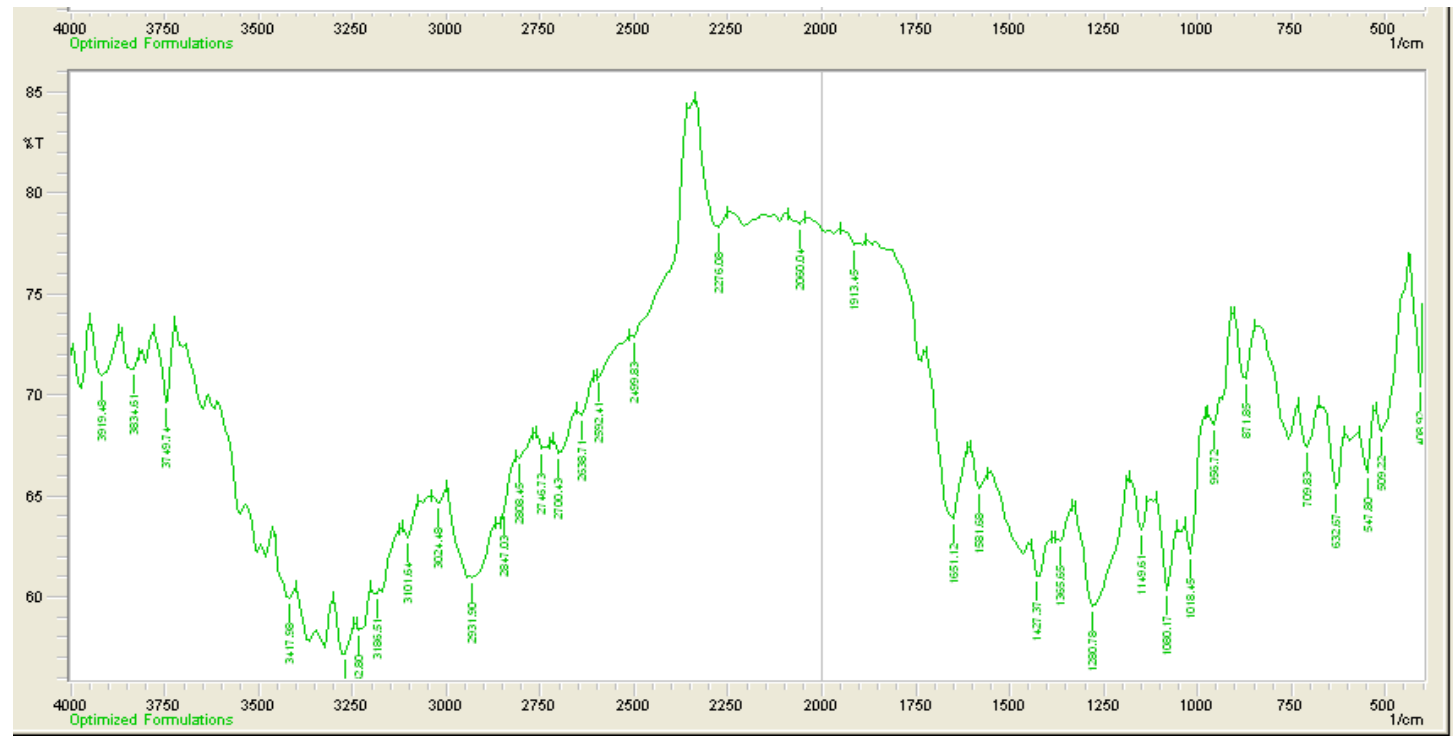

Fig. 4: FTIR of optimized formulation (A9)

Table 4: Precompression parameters evaluations

\begin{tabular}{|c|c|c|c|c|c|}
\hline Batch no & ${ }^{*}$ Bulk density (g/ml) & ${ }^{*}$ Tapped density $(\mathrm{g} / \mathrm{ml})$ & ${ }^{*}$ Compressibility index (\%) & ${ }^{*}$ Hausner's ratio & ${ }^{*}$ Angle of repose $\left({ }^{\circ}\right)$ \\
\hline A1 & $0.35 \pm 0.045$ & $0.40 \pm 0.032$ & $12.5 \pm 0.02$ & $1.14 \pm 0.13$ & $27.87 \pm 0.04$ \\
\hline $\mathrm{A} 2$ & $0.35 \pm 0.041$ & $0.40 \pm 0.040$ & $12.68 \pm 0.01$ & $1.14 \pm 0.11$ & $28.73 \pm 0.11$ \\
\hline A3 & $0.36 \pm 0.046$ & $0.41 \pm 0.036$ & $11.38 \pm 0.05$ & $1.13 \pm 0.12$ & $27.58 \pm 0.06$ \\
\hline A4 & $0.36 \pm 0.042$ & $0.42 \pm 0.038$ & $13.12 \pm 0.05$ & $1.16 \pm 0.11$ & $29.03 \pm 0.12$ \\
\hline A5 & $0.35 \pm 0.043$ & $0.40 \pm 0.042$ & $11.10 \pm 0.12$ & $1.14 \pm 0.12$ & $29.31 \pm 0.11$ \\
\hline A6 & $0.36 \pm 0.042$ & $0.41 \pm 0.041$ & $12.89 \pm 0.01$ & $1.13 \pm 0.13$ & $27.05 \pm 0.13$ \\
\hline A7 & $0.35 \pm 0.046$ & $0.41 \pm 0.045$ & $14.84 \pm 0.06$ & $1.17 \pm 0.11$ & $29.98 \pm 0.14$ \\
\hline A8 & $0.36 \pm 0.043$ & $0.41 \pm 0.046$ & $13.34 \pm 0.02$ & $1.13 \pm 0.11$ & $30.58 \pm 0.11$ \\
\hline A9 & $0.36 \pm 0.045$ & $0.42 \pm 0.039$ & $13.67 \pm 0.04$ & $1.16 \pm 0.12$ & $28.13 \pm 0.12$ \\
\hline
\end{tabular}

(*all values are expressed as mean $n=3, \pm S D$ : standard deviations)

Table 5: Evaluation of all batches of chlorpheneramine maleate

\begin{tabular}{|c|c|c|c|c|c|}
\hline Batch no & $\begin{array}{l}* \text { Hardness } \\
(\mathrm{kg} / \mathrm{cm} 2)\end{array}$ & $\begin{array}{l}\text { Thickness } \\
\text { (mm) }\end{array}$ & $\begin{array}{l}\text { *Friability } \\
(\%)\end{array}$ & $\begin{array}{l}\text { *Wetting time } \\
\text { (s) }\end{array}$ & *Water absorption ratio (\%) \\
\hline A1 & $3.2 \pm 0.1$ & 3.22 & $0.70 \pm 0.11$ & $42 \pm 1.23$ & $73.79 \pm 2.28$ \\
\hline $\mathrm{A} 2$ & $3.3 \pm 0.11$ & 3.23 & $0.68 \pm 0.13$ & $45 \pm 1.45$ & $71.23 \pm 1.15$ \\
\hline A3 & $3.1 \pm 0.21$ & 3.23 & $0.62 \pm 0.11$ & $41 \pm 0.24$ & $72.60 \pm 1.23$ \\
\hline A4 & $3.2 \pm 0.2$ & 3.22 & $0.64 \pm 0.06$ & $40 \pm 0.62$ & $70.00 \pm 1.48$ \\
\hline A5 & $3.1 \pm 0.1$ & 3.22 & $0.62 \pm 0.02$ & $42 \pm 1.12$ & $70.94 \pm 0.28$ \\
\hline A6 & $3.3 \pm 0.23$ & 3.23 & $0.60 \pm 0.15$ & $40 \pm 1.86$ & $74.48 \pm 0.56$ \\
\hline A7 & $3.4 \pm 0.12$ & 3.22 & $0.59 \pm 0.11$ & $36 \pm 0.25$ & $70.27 \pm 0.27$ \\
\hline A8 & $3.2 \pm 0.1$ & 3.25 & $0.58 \pm 0.03$ & $38 \pm 0.72$ & $72.29 \pm 0.41$ \\
\hline A9 & $3.2 \pm 0.1$ & 3.23 & $0.51 \pm 0.07$ & $32 \pm 1.46$ & $75.86 \pm 0.35$ \\
\hline
\end{tabular}

(*all values are expressed as mean $n=3, \pm \mathrm{SD}$ : standard deviations)

Table 6: Evaluation of all batches of chlorpheneramine maleate

\begin{tabular}{lllll}
\hline Batch no & $*$ Weight variation (mg) & $*$ Disintegration time (s) & Drug content (\%) & In vitro drug release (\%) \\
\hline A1 & $146 \pm 2.36$ & $39 \pm 1.20$ & 97.52 & 97.59 \\
A2 & $145 \pm 2.45$ & $40 \pm 1.25$ & 98.55 & 93.72 \\
A3 & $149 \pm 2.18$ & $36 \pm 2.48$ & 97.54 & 95.78 \\
A4 & $148 \pm 1.25$ & $34 \pm 1.59$ & 97.5 & 96.42 \\
A5 & $145 \pm 1.48$ & $31 \pm 2.16$ & 102.50 & 97.58 \\
A6 & $147 \pm 1.36$ & $33 \pm 0.98$ & 96.63 & 98.67 \\
A7 & $145 \pm 2.69$ & $30 \pm 0.56$ & 102.50 & 99.45 \\
A8 & $146 \pm 2.48$ & $28 \pm 1.27$ & 98.75 & 99.51 \\
A9 & $146 \pm 2.45$ & $26 \pm 0.36$ & & \\
\hline
\end{tabular}

(*all values are expressed as mean $n=3, \pm S D$ : standard deviations), Disintegration time-Optimized formulation A (9) showed the least disintegration time 26 s., Drug content-Drug content of Optimized formulation A (9) was found to be $98.75 \%$., \% drug release-Optimized formulation A (9) showed a $99.77 \%$ drug release within 6 min. (fig. 5). 


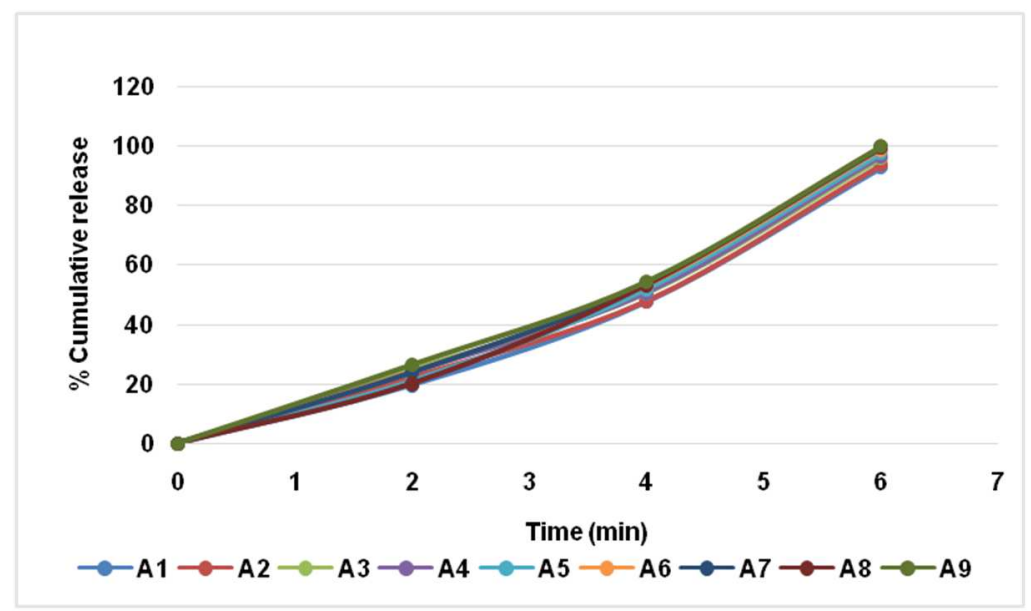

Fig. 5: \% cumulative release of drug

\section{Factorial design}

Table 7: Formulation and disintegration time and percentage friability characteristics of factorial batches

\begin{tabular}{lllll}
\hline Batches code & \multicolumn{2}{l}{ Variable level in coded form } & Disintegration time (s) & \% Friability \\
\cline { 2 - 5 } & $\mathbf{X}_{\mathbf{1}}$ & $\mathbf{X}_{\mathbf{2}}$ & & $0.70 \pm 0.11$ \\
$\mathrm{~A}_{1}$ & -1 & -1 & $39 \pm 1.20$ & $0.68 \pm 0.13$ \\
$\mathrm{~A}_{2}$ & -1 & 0 & $40 \pm 1.25$ & $0.62 \pm 0.11$ \\
$\mathrm{~A}_{3}$ & -1 & +1 & $36 \pm 2.48$ & $0.64 \pm 0.06$ \\
$\mathrm{~A}_{4}$ & 0 & -1 & $34 \pm 1.59$ & $0.62 \pm 0.02$ \\
$\mathrm{~A}_{5}$ & 0 & 0 & $31 \pm 2.16$ & $0.60 \pm 0.15$ \\
$\mathrm{~A}_{6}$ & 0 & +1 & $33 \pm 0.98$ & $0.59 \pm 0.11$ \\
$\mathrm{~A}_{7}$ & +1 & -1 & $30 \pm 0.56$ & $0.58 \pm 0.03$ \\
$\mathrm{~A}_{8}$ & +1 & 0 & $28 \pm 1.27$ & $0.51 \pm 0.07$ \\
$\mathrm{~A}_{9}$ & +1 & +1 & $26 \pm 0.36$ & \\
\hline
\end{tabular}

( $\mathrm{X}_{1}$-Crospovidone, $\mathrm{X}_{2}$-Croscarmellose sodium)

The concentration of Crospovidone(X1) and Croscarmellose sodium (X2) were selected as an independent variable. A statistical model,

$$
\mathrm{Y}=\mathrm{b}_{0}+\mathrm{b}_{1} \mathrm{X}_{1}+\mathrm{b}_{2} \mathrm{X}_{2}+\mathrm{b}_{12} \mathrm{X}_{1} \mathrm{X}_{2}+\mathrm{b}_{11} \mathrm{X}_{1}^{2}+\mathrm{b}_{12} \mathrm{X}_{2}^{2},
$$

Incorporating interactive and polynomial terms was used to evaluate response. The data obtained after the evaluation of factorial batches were analyzed using commercially available software minitab $₫ 18$. The disintegration time and percentage friability show wide variation for nine batches (A1 to A9), i. e (26-39 s, 0.51-0.70\%). The data clearly confirmed that disintegration time and percentage friability are strongly depended on independent variables.

\section{Disintegration time}

The polynomial equation was found to be-

$$
\mathrm{Y}(\text { disintegration time })=45.83-1.000 \mathrm{X}_{1}-0.3000 \mathrm{X}_{2} \ldots \ldots \ldots . . .
$$

The-ve sign for $\mathrm{X} 1$ and $\mathrm{X} 2$ indicates that as the concentration of super disintegrant increases disintegration time decreases. The surface response plot shows the effect of Crospovidone and Croscarmellose sodium (fig. 6). The model was considered as significant with $(\mathrm{p}<0.05)$ value 0.002 .

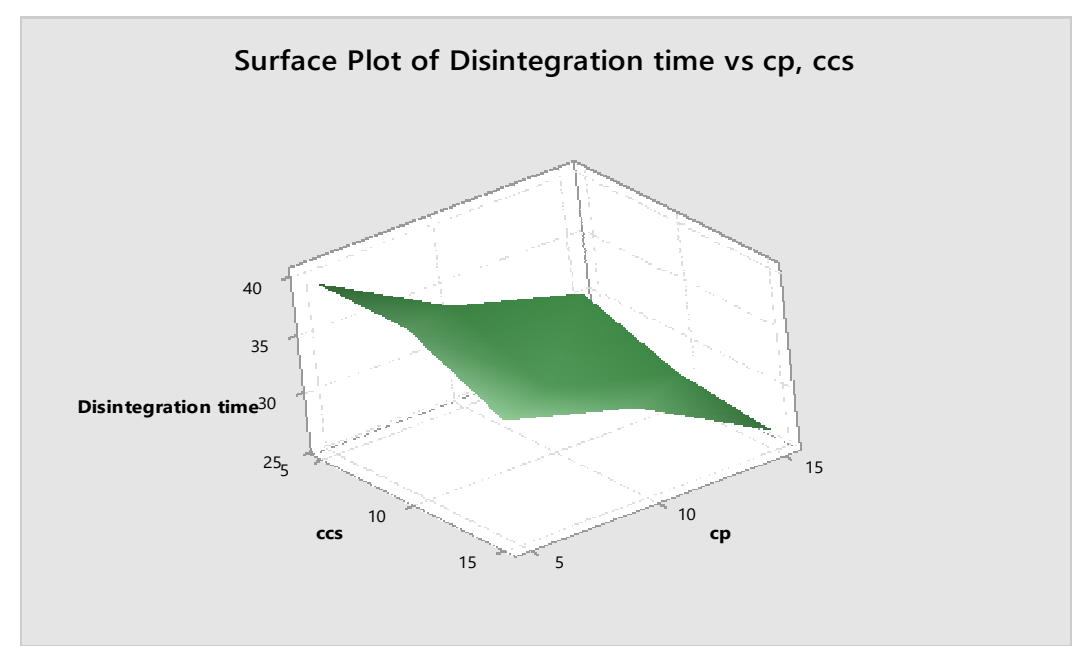

Fig. 6: Surface plot for disintegration time 


\section{$\%$ friability}

The polynomial equation was found to be-

$\mathrm{Y}(\%$ friability $)=0.7467-0.011167 \mathrm{X}_{1}+0.00300 \mathrm{X}_{2} \ldots \ldots$. equation 2
The-ve sign for X1 indicates that as the concentration of super disintegrant increases, friability decreases. The surface response plot shows the effect of Crospovidone and Croscarmellose sodium (fig. 7). Model is considered significant with $(\mathrm{p}<0.05)$ value 0.029 .

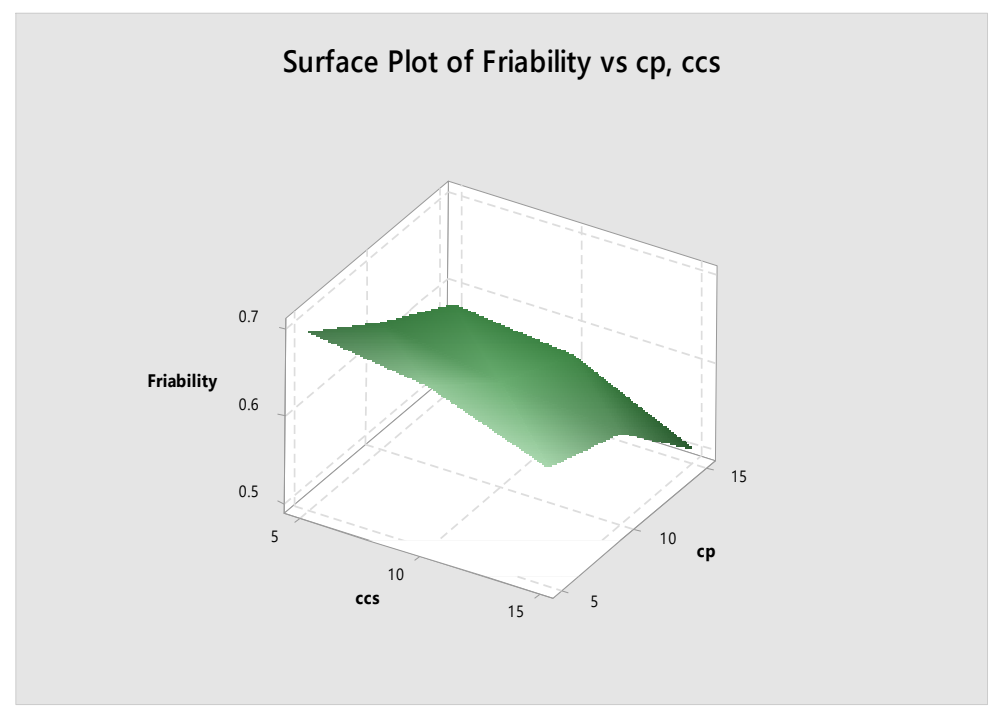

Fig. 7: Surface plot for $\%$ friability

Table 8: Stability data

\begin{tabular}{lll}
\hline Parameters & Initial & After $\mathbf{3}$ mo stability study \\
\hline Appearance & White & White \\
Disintegration time & $26 \mathrm{~s}$ & $24 \mathrm{~s}$ \\
Hardness & $3.2 \mathrm{~kg} / \mathrm{cm} 2$ & $3.1 \mathrm{~kg} / \mathrm{cm} 2$ \\
\hline
\end{tabular}

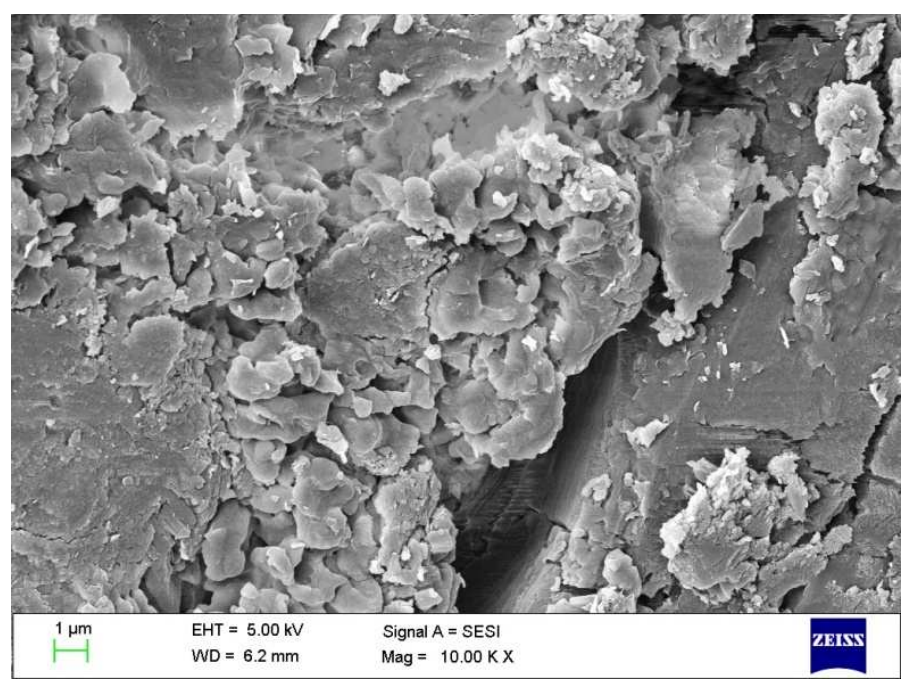

Fig. 8: SEM of optimized formulation A (9)

\section{Stability study}

Optimized formulation A (9) was kept for the stability test for three mo. After three mo, it was seen that formulation was stable. Results were summarized in (table 8).

\section{SEM analysis}

SEM study revealed the formation of a porous structure within the tablet. Optimized formulation A (9) was analyzed for SEM and Shown in fig. 8

\section{DISCUSSION}

Camphor was selected as a sublimating agent in this present work. To determine the optimized concentration of camphor, preliminary batches were carried out with different concentrations of the sublimating agent. The disintegration time values for all batches were mentioned in table 1 . Batch N (3) with $20 \mathrm{mg}$ camphor showed the least disintegration time as compared to others due to the development of the higher porous structure. So, a higher concentration of sublimating agent was used in further study. 
Mannitol was used as diluent due to its negative heat of dissolution, good mouth feels. Microcrystalline cellulose was dropped out from study because sometimes it causes grittiness in the mouth. Crospovidone and Croscarmellose sodium were used as super disintegrants. They showed capillary action of a mechanism. Saccharin sodium and the orange flavor were used as taste-masking agent.

DSC of pure drug sample showed a sharp endothermic peak at 135 ${ }^{\circ} \mathrm{C}$ which was near to its melting point range $\left(130-135{ }^{\circ} \mathrm{C}\right)$. The nature of the peak showed the purity of the drug sample. DSC of optimized formulation A (9) showed that there were no interactions between drug and excipients. The FTIR of pure drug and an optimized batch A (9) showed all peak ranges are uniform. $\mathrm{NH}$ stretch (primary amine) of pure drug obtained at $3225.95 \mathrm{~cm}^{-1}$ and that of an optimized batch showed at $3271.38 \mathrm{~cm}^{-1}$. CH stretch (alkane) of the pure drug showed a peak at $3009.05 \mathrm{~cm}^{-1}$ and that of optimized formulation showed at $2931.90 \mathrm{~cm}^{-1}$. C-N (aromatic nuclei) showed a peak at $1273.06 \mathrm{~cm}^{-1}$ for pure drug and for optimized formulation at $1365.65 \mathrm{~cm}^{-1}$. DSC and FTIR study showed that drug and excipients are compatible with each other.

Tablet blend was analyzed for bulk density, tapped density, compressibility index, Hausner's ratio, angle of repose. All parameters for batch A (1) to A (9) were within the limit and showed good flow property. Hardness and thickness for all formulation were found to be uniform and within the range that showed good mechanical strength for tablets. \% friability for all formulation was found to be within the IP limit $(<1 \%)$ indicating its good mechanical strength. A (9) formulation showed less \% friability as compared to other formulations due to the higher concentration of Crospovidone which was essential for making less friable tablets. Lower wetting time gives faster disintegration in A (9) as compared to others. A Higher absorption ratio of an optimized batch is directly proportional to its dissolution rate.

All batches were passed weight variation test as per IP limit. The permissible limit was $\pm 7.5 \%$.

Batch A (9) showed the least disintegration time with $10 \%$ Crospovidone and $10 \%$ Croscarmellose sodium as compared to other formulations. The Higher concentration of super disintegrants was essential for the rapid disintegration of the tablet. Tablet prepared by direct compression technique showed disintegration time at $3 \mathrm{~min}$ [12]. So, as per the above result sublimation technique was better than the direct compression method. Drug content for all batches was within the limit 95.0 to $105.0 \%$ meeting to the IP 2010 specification limit of chlorpheneramine maleate. Optimized formulation A (9) showed higher drug release 99.77\% within 6 min. Tablet prepared by the direct compression method showed drug release $94.95 \%$ within $45 \mathrm{~min}$ [12]. It showed that the sublimation technique gives faster release than direct compression. The concentration of Crospovidone and Croscarmellose sodium was selected as an independent variable and disintegration time, \% friability was selected as the dependent variable in $3^{2}$ factorial studies. The result showed that the dependent variables strongly depend on independent variables.

As the concentration of super disintegrant increases, disintegration time and and \% friability decreases. The Model considered as significant. The stability study showed that there were no major changes made on tablets. SEM study showed that sublimation of camphor formed the porous structure in the tablet matrix which was essential for the rapid disintegration of the tablet.

\section{CONCLUSION}

The current study revealed the successful formation of the orally disintegrating tablet of chlorpheneramine maleate by sublimation method to avoid the first-pass metabolism of the drug and improves patient compliance. Batch A (9) showed an optimized result for drug release and disintegration time. It was confirmed that as the concentration of super disintegrants increase, disintegration time decreases. The factorial study revealed that disintegration time and $\%$ friability depends on independent variables.

\section{ACKNOWLEDGMENT}

We are thankful to all industries for providing a sample of drug and excipients respectively. We are thankful to our college for providing facilities to complete the research work.

\section{AUTHORS CONTRIBUTIONS}

Experimental designs, guidance, attention, support, help for the research work was done by Mr. N. R. Bhosale. Literature review, experimental work, optimization and interpretation of results were carried out by Miss. Nikita Kolte.

\section{CONFLICT TO INTERESTS}

\section{Declared none}

\section{REFERENCES}

1. More SA, Mohite SK. Orodispersible tablet: a novel drug delivery system. J Pharm Sci Technol 2012;4:798-806.

2. Bhowmik D, Chiranjib B, Krishnkanth, Pankaj, Chandira RM. Fast dissolving tablet: an overview. J Chem Pharm Res 2009;1:163-77.

3. Chauhan K, Solanki R, Sharma S. A review: on fast dissolving tablet. Int J Appl Pharm 2018;10:1-7.

4. Deshmukh KR, Patel V, Verma S, Pandey AK, Dewangan P. A review: on mouth dissolving tablet techniques. Int J Res Ayurveda Pharm 2011;2:66-74.

5. Sharma N, Sharma J, Jat RC, Rathore A. Fast dissolving tablet as novel dosage form. Int J Res Lett Sci 2012;1:99-104.

6. Patil PB. Recent trends in orodispersible tablets: an overview of formulation technology and future prospects. Int J Pharm Sci Res 2015;6:1056-66.

7. Aher SS, Saudagar RB, Shinde MS. Review: fast dissolving tablet. Int J Curr Pharm Res 2018;10:5-12.

8. Singh S, Verma N. Taste masked orodispersible tablets: a highly patient complaint dosage form. Asian J Pharm Clin Res 2016;9:385-91.

9. Sharma D. Taste masking technologies: a novel approach for the improvement of organoleptic property of pharmaceutical active substance. Int Res J Pharm 2012;3:108-16.

10. Dave V, Yadav RB, Ahuja R, Sahu K. Formulation and evaluation of orally dispersible tablets of chlorpheneramine maleate by fusion method. Marmara Pharm J 2017;21:67-77.

11. Elbakry AM, Elosaily GH, Yassin GE, Zaky AA. Design and assessment of chlorpheneramine maleate sublingual tablets using novel ternary phase superdisintegrants. Am J Sci 2014;10:125-34.

12. Ali H, Muhammad HS. Formulation development of chlorpheneramine maleate tablet by direct compression. Jordan J Pharm Sci 2011;4:1-7.

13. Razak KA, Seetha Dvi A, Anka Rao A, Vasu Naik V. Orally disintegrating tablet: review. Int J Pharma Chem Res 2015;1:25-30.

14. Pandey P, Dahiya M. Oral disintegrating tablets: review. Int J Pharma Res Rev 2016;5:50-62.

15. Rawat S, Derle DV, Fukte SR, Shinde PR. Superdisintegrants: an overview. World J Pharm Pharm Sci 2014;3:263-78.

16. Pahwa R, Gupta N. Superdisintegrants in the development of orally disintegrating tablet: a review. Int J Pharm Sci Res 2011;2:2767-80.

17. Yadav G, Kapoor A, Bhargava S. Fast dissolving tablets recent advantages: a review. Int J Pharm Sci Res 2012;3:728-36.

18. Ramana G, Leela K, Roy D. Formulation and evaluation of oral disintegrated tablets of alfuzosin hydrochloride using super disintegrants. J Appl Pharm Sci 2011;1:161-5.

19. Basu B, Bagadiya A, Makwana S, Vora V, Batt D, Dharamsi A. Formulation and evaluation of fast dissolving tablets of cinnarizine using super disintegrants blends and subliming material. J Adv Pharm Technol Res 2011;2:266-73.

20. Purkayastha HD, Nath B. Formulation and evaluation of oral fast disintegrating tablet of ibuprofen using two superdisintegrants. Int J Curr Pharm Res 2017;9:92-5 
21. Monva B, Laxman kumar D, Ravi kumar KM. Formulation and evaluation of fast dissolving tablet of Ranitidine HCL by hole technology. Asian J Pharm Clin Res 2013;6:143-7.

22. Mohanchandran PS. Formulation and evaluation of mouth dispersible tablet of amlodipine besylate. Int J Appl Pharm 2018;2:1-6.

23. Pathan I, Shingare P, Kurumkar P. Formulation design and optimization of novel mouth dissolving tablets for venlafaxine hydrochloride using sublimation technique. J Pharm Res 2013;6:593-8.
24. Gaur K, Tyagi L, Kori M, Sharma CS. Formulation and characterisation of fast disintegrating tablets of aceclofenac by using sublimation method. Int J Pharm Sci Drug Res 2011;3:19-22.

25. Mothilal M, Harish Kumar A, V Manasa, V Manimaran. Formulation and evaluation of modafinil fast dissolving tablets by sublimation technique. J Chem Pharm Res 2013;6:147-54.

26. Okhuelegbe E, Ikhuoria A, Ike A. Evaluation of fast disintegrating tablets of nifedipine prepared by superdisintegrant addition and sublimation method. Dhaka Univ J Pharm Sci 2014;13:199-205. 